\title{
Front Matter: Volume 7324
}

, "Front Matter: Volume 7324," Proc. SPIE 7324, Atmospheric Propagation VI, 732401 (28 May 2009); doi: 10.1117/12.833832

SPIE Event: SPIE Defense, Security, and Sensing, 2009, Orlando, Florida, United SPIE. States 


\section{PROCEEDINGS OF SPIE}

\section{Atmospheric Propagation VI}

Linda M. Wasiczko Thomas

G. Charmaine Gilbreath

Editors

14-16 April 2009

Orlando, Florida, United States

Sponsored and Published by

SPIE

Volume 7324 
The papers included in this volume were part of the technical conference cited on the cover and title page. Papers were selected and subject to review by the editors and conference program committee. Some conference presentations may not be available for publication. The papers published in these proceedings reflect the work and thoughts of the authors and are published herein as submitted. The publisher is not responsible for the validity of the information or for any outcomes resulting from reliance thereon.

Please use the following format to cite material from this book:

Author(s), "Title of Paper," in Atmospheric Propagation VI, edited by Linda M. Wasiczko Thomas, G. Charmaine Gilbreath, Proceedings of SPIE Vol. 7324 (SPIE, Bellingham, WA, 2009) Article CID Number.

ISSN 0277-786X

ISBN 9780819475909

Published by

SPIE

P.O. Box 10, Bellingham, Washington 98227-0010 USA

Telephone +1 3606763290 (Pacific Time) · Fax +1 3606471445

SPIE.org

Copyright (C) 2009, Society of Photo-Optical Instrumentation Engineers

Copying of material in this book for internal or personal use, or for the internal or personal use of specific clients, beyond the fair use provisions granted by the U.S. Copyright Law is authorized by SPIE subject to payment of copying fees. The Transactional Reporting Service base fee for this volume is $\$ 18.00$ per article (or portion thereof), which should be paid directly to the Copyright Clearance Center (CCC), 222 Rosewood Drive, Danvers, MA 01923. Payment may also be made electronically through CCC Online at copyright.com. Other copying for republication, resale, advertising or promotion, or any form of systematic or multiple reproduction of any material in this book is prohibited except with permission in writing from the publisher. The CCC fee code is 0277-786X/09/ $\$ 18.00$.

Printed in the United States of America.

Publication of record for individual papers is online in the SPIE Digital Library.

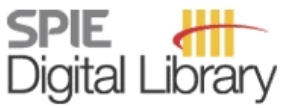

SPIEDigitalLibrary.org

Paper Numbering: Proceedings of SPIE follow an e-First publication model, with papers published first online and then in print and on CD-ROM. Papers are published as they are submitted and meet publication criteria. A unique, consistent, permanent citation identifier (CID) number is assigned to each article at the time of the first publication. Utilization of CIDs allows articles to be fully citable as soon they are published online, and connects the same identifier to all online, print, and electronic versions of the publication. SPIE uses a six-digit CID article numbering system in which:

- The first four digits correspond to the SPIE volume number.

- The last two digits indicate publication order within the volume using a Base 36 numbering system employing both numerals and letters. These two-number sets start with 00, 01, 02, 03, 04, $05,06,07,08,09,0 A, 0 B \ldots 0 Z$, followed by 10-1Z, 20-2Z, etc.

The CID number appears on each page of the manuscript. The complete citation is used on the first page, and an abbreviated version on subsequent pages. Numbers in the index correspond to the last two digits of the six-digit CID number. 


\section{Contents}

vii Conference Committee
ix Introduction

SESSION 1 THEORY, MODELING, AND SIMULATION I

$732402 \quad$ Near-ground vertical profile of refractive-index fluctuations (Invited Paper) [7324-01]

L. C. Andrews, R. L. Phillips, D. Wayne, T. Leclerc, P. Saver, R. Crabbs, Univ. of Central Florida (United States); J. Kiriazes, NASA Kennedy Space Ctr. (United States)

732403 Laser beam propagation in the low-order turbulence: exact solution [7324-02]

M. Charnotskii, Zel Technologies, LLC (United States) and NOAA Earth System Research Lab. (United States)

732404 Simulation and theory of speckle noise for an annular aperture frequency-modulation differential-absorption LIDAR (FM-DIAL) system [7324-03]

P. E. Keller, M. T. Batdorf, J. D. Strasburg, W. W. Harper, Pacific Northwest National Lab. (United States)

\section{SESSION 2 THEORY, MODELING, AND SIMULATION II}

732406 Availability of free-space optical communication systems under influence of beam wandering and optical turbulence [7324-05]

J. P. G. de Oliveira, Univ. Karlsruhe (Germany)

732407 A survey of apodization functions for diffraction-free propagation [7324-06]

G. J. Baker, Lockheed Martin Advanced Technology Ctr. (United States)

\section{SESSION 3 EXPERIMENTAL STUDIES I}

732409 Optical propagation in the underwater environment (Invited Paper) [7324-09]

L. Mullen, Naval Air Systems Command (United States)

7324 OA Optical homodyne RZ-QPSK transmission through wind tunnel at 3.8 and $1.55 \mu \mathrm{m}$ via wavelength conversion [7324-10]

P. S. Cho, G. Harston, CeLight, Inc. (United States); K.-D. F. Büchter, Univ. Paderborn

(Germany); D. Soreide, Optimal Aerospace (United States); J. M. Saint Clair, The Boeing Co.

(United States); W. Sohler, Univ. Paderborn (Germany); Y. Achiam, I. Shpantzer, CeLight, Inc. (United States)

$7324 \mathrm{OB} \quad$ Analysis of rapid $\mathrm{C}_{\mathrm{n}}{ }^{2}$ fluctuations observed during a 5-km communication link experiment [7324-11]

T. M. Yarnall, S. S. Michael, J. D. Moores, R. R. Parenti, W. E. Wilcox, Jr., MIT Lincoln Lab. (United States) 
7324 OC Inversion techniques for the differential image motion lidar [7324-12]

I. Gatland, Georgia Institute of Technology (United States); J. M. Stewart, G. G. Gimmestad, Georgia Tech Research Institute (United States)

7324 OD Statistical properties of a short analog RF free-space optical link [7324-13]

F. Bucholtz, H. R. Burris, C. I. Moore, C. S. McDermitt, R. Mahon, M. R. Suite, Naval Research Lab. (United States); J. V. Michalowicz, Global Strategies Group, North America, Inc. (United States); G. C. Gilbreath, W. S. Rabinovich, Naval Research Lab. (United States)

\section{SESSION 4 EXPERIMENTAL STUDIES II}

$7324 \mathrm{OE} \quad$ Conceptual designs of onboard transceivers for ground-to-satellite quantum cryptography [7324-14]

M. Toyoshima, Y. Shoji, Y. Takayama, H. Kunimori, M. Takeoka, M. Fujiwara, M. Sasaki, National Institute of Information and Communications Technology (Japan)

7324 OF Free space optical communication flight mission: simulations and experimental results on ground level demonstrator [7324-15]

R. Mata Calvo, V. Ferrero, Politecnico di Torino (Italy) and Istituto Superiore Mario Boella (Italy); S. Camatel, Istituto Superiore Mario Boella (Italy); V. Catalano, Agenzia Spaziale Italiana (Italy); L. Bonino, Thales Alenia Space Italia (Italy); I. Toselli, Politecnico di Torino (Italy)

7324 OG Long range analog RF free space optical communication link in a maritime environment [7324-16]

H. R. Burris, F. Bucholtz, C. I. Moore, Naval Research Lab. (United States); K. J. Grant, Defence Science and Technology Organisation (Australia); M. R. Suite, C. S. McDermitt, Naval Research Lab. (United States); B. A. Clare, Defence Science and Technology Organisation (Australia); R. Mahon, Naval Research Lab. (United States); W. Martinsen, Defence Science and Technology Organisation (Australia); M. Ferraro, Naval Research Lab. (United States); R. Sawday, Defence Science and Technology Organisation (Australia); B. Xu, C. Font, L. M. Thomas, Naval Research Lab. (United States); K. A. Mudge, Defence Science and Technology Organisation (Australia); W. S. Rabinovich, G. C. Gilbreath, W. Scharpf, Naval Research Lab. (United States); E. Saint-Georges, S. Uecke, NovaSol (United States)

$7324 \mathrm{OH} \quad$ Evaluation of a novel FSO receiver for mitigating alignment errors [7324-17] S. Spaunhorst, P. G. LoPresti, S. Pondelik, The Univ. of Tulsa (United States); H. Refai, Univ. of Oklahoma (United States)

\section{SESSION 5 EXPERIMENTAL STUDIES III}

7324 0J Comparison of scintillation measurements from a $5 \mathbf{~ k m}$ communication link to standard statistical models [7324-19]

S. Michael, R. R. Parenti, F. G. Walther, A. M. Volpicelli, J. D. Moores, W. Wilcox, Jr., R. Murphy, MIT Lincoln Lab. (United States)

7324 OK Evaluation of free-space optical fiber bundle transmitter configurations for receiver tracking [7324-20]

D. Zhou, P. G. LoPresti, N. Brooks, The Univ. of Tulsa (United States); H. Refai, Univ. of Oklahoma (United States) 
$7324 \mathrm{OL} \quad$ Challenges facing mobile free-space optical communications [7324-21]

M. K. Al-Akkoumi, Univ. of Oklahoma, Tulsa (United States); A. Harris, Univ. of North Florida

(United States); R. C. Huck, J. J. Sluss, Jr., Univ. of Oklahoma, Tulsa (United States)

\section{SESSION 6 EXPERIMENTAL STUDIES IV}

7324 OM Mitigation of weak and strong turbulence-induced fading in optical homodyne RZ-QPSK via delay-diversity transmission [7324-22]

P. S. Cho, G. Harston, CeLight, Inc. (United States); D. Soreide, Optimal Aerospace (United States); J. M. Saint Clair, The Boeing Co. (United States); Y. Achiam, I. Shpantzer, CeLight, Inc. (United States)

$7324 \mathrm{ON}$ Theoretical and experimental results for 1550-nm light scattering in clouds and their predictions for pulse broadening effects on high-throughput optical communications [7324-23]

G. J. Martin, W. R. Christian, J. E. Mansell, J. Ma, B. K. Winker, Teledyne Scientific Co. (United States)

$732400 \quad$ Integrated atmospheric characterization system [7324-24]

D. W. Roberts, G. G. Gimmestad, J. M. Stewart, Georgia Tech Research Institute (United States); D. N. Whiteman, NASA Goddard Space Flight Ctr. (United States); F. D. Eaton, Air Force Research Lab. (United States)

$7324 \mathrm{OP} \quad$ An atmospheric turbulence, scattering, and weather monitoring system for three kilometers, partially over water path for monitoring the statistics of turbulence [7324-25]

A. V. Sergeyev, M. C. Roggemann, C. Middlebrook, Michigan Technological Univ. (United States); P. Piatrou, Univ. of California, Irvine (United States); W. Yang, K. Drexler, C. Demars, Michigan Technological Univ. (United States)

\section{SESSION $7 \quad$ ACTIVE AND PASSIVE SIGNATURES WORKSHOP I}

$7324 O Q \quad$ Technical intelligence and the operational art (Keynote Paper) [7324-26]

J. B. Longley, DIRITECH, LLC (United States)

7324 OR Airborne measurements in the infrared using FTIR-based imaging hyperspectral sensors [7324-46]

E. Puckrin, C. S. Turcotte, P. Lahaie, D. Dubé, Defence Research and Development Canada, Valcartier (Canada); V. Farley, P. Lagueux, F. Marcotte, M. Chamberland, Telops Inc. (Canada)

7324 OT Characterization and training of a piezoelectric deformable mirror for operation at $1550 \mathrm{~nm}$ [7324-30] C. O. Font, G. C. Gilbreath, B. Bajramaj, D. S. Kim, F. Santiago, T. Martinez, S. R. Restaino, Naval Research Lab. (United States)

$7324 \mathrm{OU} \quad$ Optical signatures for autonomous mobility [7324-31] M. A. Powers, C. C. Davis, General Dynamics (United States) and Univ. of Maryland, College Park (United States) 
7324 OW The use of spider webs as passive bioaerosol collectors [7324-34]

D. I. Mattei, C. A. Bleckmann, D. J. Bunker, Air Force Institute of Technology (United States); I. Maxis, National MASINT Management Office (United States)

\section{SESSION $8 \quad$ ACTIVE AND PASSIVE SIGNATURES WORKSHOP II}

7324 OX Multiple-coincidence interrogation of fissionables [7324-35]

J. P. Hurley, R. P. Keegan, J. R. Tinsley, R. Trainham, National Security Technologies, LLC (United States)

7324 OY Integrated passive electronic signature modeling [7324-36]

M. K. Bole, J. McGraw, Photon Research Associates (United States); F. Ryan, U.S. Navy SPAWAR Systems Ctr., Pacific (United States); T. Hawley, Signature Support Program (United States); M. Davis, T. Van, Photon Research Associates (United States)

$7324 \mathrm{OZ}$ Terahertz spectral signatures of explosive materials and precursors [7324-37]

C. D. Ball, T. J. Ronningen, L. C. Oesterling, Battelle Memorial Institute (United States)

732410 A computational tool for evaluating THz imaging performance in brownout conditions at land sites throughout the world [7324-38]

S. T. Fiorino, R. J. Bartell, M. J. Krizo, S. L. Marek, M. J. Bohn, R. M. Randall, S. J. Cusumano, Air Force Institute of Technology (United States)

$732411 \quad$ NIST speaker recognition evaluations 1996-2008 [7324-39]

A. F. Martin, C. S. Greenberg, National Institute of Standards and Technology (United States)

732413 Multimodal signature file formats and performance in computational environments

[7324-41]

K. Bennett, Army Research Lab. (United States); J. Robertson, Clearhaven Technologies LLC (United States)

\section{WORKSHOP SUMMARY}

732417 Signatures support program [7324-47]

C. T. Hawley, Signatures Support Program (United States)

Author Index 


\title{
Conference Committee
}

\author{
Symposium Chair
}

Ray O. Johnson, Lockheed Martin Corporation (United States)

Symposium Cochair

Michael T. Eismann, Air Force Research Laboratory (United States)

Conference Chairs

Linda M. Wasiczko Thomas, Naval Research Laboratory (United States)

G. Charmaine Gilbreath, Naval Research Laboratory (United States)

Program Committee

Larry C. Andrews, University of Central Florida (United States)

Gary J. Baker, Lockheed Martin Advanced Technology Center (United States)

Harris Rayvon Burris, Jr., Naval Research Laboratory (United States)

John J. Degnan, Sigma Space Corporation (United States)

Georges R. Fournier, Defence R\&D Canada, Valcartier (Canada)

Gary G. Gimmestad, Georgia Tech Research Institute (United States)

Kenneth J. Grant, Defence Science and Technology Organisation (Australia)

Christopher I. Moore, Naval Research Laboratory (United States)

Sergio R. Restaino, Naval Research Laboratory (United States)

Jennifer C. Ricklin, Defense Advanced Research Projects Agency

(United States)

Jonathan M. Saint Clair, The Boeing Company (United States)

Ove K. Steinvall, Swedish Defence Research Agency (Sweden)

Cynthia Y. Young, University of Central Florida (United States)

\section{Session Chairs}

1 Theory, Modeling, and Simulation I

Gary J. Baker, Lockheed Martin Advanced Technology Center (United States)

2 Theory, Modeling, and Simulation II

Jonathan M. Saint Clair, The Boeing Company (United States)

3 Experimental Studies I

Linda M. Wasiczko Thomas, Naval Research Laboratory (United States) 
4 Experimental Studies II

Gary G. Gimmestad, Georgia Tech Research Institute (United States)

5 Experimental Studies III

Harris R. Burris, Jr., Naval Research Laboratory (United States)

6 Experimental Studies IV

Michelle R. Suite, Naval Research Laboratory (United States)

$7 \quad$ Active and Passive Signatures Workshop I

Chadwick T. Hawley, Signatures Support Program (United States)

G. Charmaine Gilbreath, Naval Research Laboratory (United States)

8 Active and Passive Signatures Workshop II

G. Charmaine Gilbreath, Naval Research Laboratory (United States)

Chadwick T. Hawley, Signatures Support Program (United States)

Workshop Summary

G. Charmaine Gilbreath, Naval Research Laboratory (United States) Chadwick T. Hawley, Signatures Support Program (United States) 


\section{Introduction}

We have reviewed another year of innovative, pertinent research in Atmospheric Propagation. In the core atmospheric propagation session, researchers from industry, academia, and government presented papers on twenty-six research topics. Many of the attendees of the conference have participated in this meeting for the past six years. We welcomed new contributors to the meeting, who brought valuable new perspectives to our scientific debates.

The theory of optical beam propagation in the atmosphere is continuously evolving, from core Kolmogorov theory, to advances by Larry Andrews and Ron Phillips, Mikhail Charnotskii, and Gary Baker. The experimenters in our community provide fuel for further theoretical developments by quantifying optical propagation relevant to aero-optics, coherence, aerosols, and varied environments and terrain. The forum that this conference provides allows researchers with different and complementary areas of interest to come together, debate, and inspire future advances in atmospheric propagation.

We had the privilege this year of expanding our conference to include a Workshop on Active and Passive Signatures. In this dynamic world, signatures are critical to the detection and identification of events. We thank Chadwick Hawley from the Signatures Support Program for his hard work in setting up a successful workshop and inspiring future work in signature science.

The members of the atmospheric propagation organizing committee would like to thank all the participants for making this year a great success. We look forward to discussing your new research results at Atmospheric Propagation VII.

\section{Linda M. Wasiczko Thomas G. Charmaine Gilbreath}


Downloaded From: https://www.spiedigitallibrary.org/conference-proceedings-of-spie on 26 Apr 2023

Terms of Use: https://www.spiedigitallibrary.org/terms-of-use 